\title{
Standardization proposal for the mapping of Caulerpa taxifolia expansion in the Mediterranean Sea
}

\author{
Jean de VAUGELAS ${ }^{a}$, Alexandre MEINESZ ${ }^{a}$, Boris ANTOLIC $^{\text {b }}$, Enrique BALLESTEROS $^{c}$, \\ Thomas BELSHER ${ }^{d}$, Nicolas CASSAR ${ }^{\text {a }}$, Giulia CECCHERELLI ${ }^{\mathrm{e}}$, Francesco CINELLI ${ }^{\mathrm{e}}$, \\ Jean-Michel COTTALORDA ", Carla FRADÀ ORESTANO ${ }^{\text {f }}$, Antoni M. GRAU ${ }^{\text {g, Andrej JAKLIN }}{ }^{\text {h, }}$ \\ Carlo MORUCCI ${ }^{i}$, Marco RELINI ${ }^{j}$, Roberto SANDULLI ${ }^{k}$, Ante SPAN ${ }^{b}$, Giuseppe TRIPALDI ${ }^{i}$, \\ Patrick VAN KLAVEREN ${ }^{1}$, Nevenka ZAVODNIK ${ }^{\text {h }}$, Ante ZULJEVIC $^{b}$
}

${ }^{a}$ Laboratoire environnement marin littoral, université de Nice-Sophia-Antipolis, faculté des sciences, campus Valrose, 06108 Nice cedex 2, France. vaugelas@unice.fr

${ }^{b}$ Laboratori of fitobenthos, Institute of Oceanography and Fisheries, I Mestrovica 63, 21000 Split, P.P. 500, Croatia. zuljevic@izor.hr

${ }^{c}$ Centre d'Estudis Avançat de Blanes- CSIC, C. Santa Barbara s/n, 17300 Blanes, Girona, Spain. kike@ ceab.es

d Ifremer, centre de Brest, département d'écologie côtière, BP 70, 29280 Plouzané cedex, France. belsher@ifremer.fr

${ }^{\text {e}}$ Dipartimento di Scienze dell'Uomo e dell'Ambiente, Università di Pisa, Via A. Volta 6, 56121 Pisa, Italy. cinelli@ discat.unipi.it

f Laboratorio di Ecologia Acquatica, Dipartimento di Scienze Botaniche, Università degli studi di Palermo, Via Archirafi 38, 90123, Palermo, Italy

g Conselleria d'Agricultura i Pesca, C/. Forners. num. 10, 07006, Palmade, Mallorca, Spain

"Laboratory for Ecology and Systematics, "Ruder Boskovic" Institute, Center for Marine Research, Obala Giordano Paliaga 5, 52210 Rovinj, Croatia. dzavodnik@ cim.irb.hr

i Castalia S.p.A., Via Vitorchiano 151, 00189 Roma, Italy

j Istituto di Zoologia, Via Balbi 5, 16126 Genova, Italy. largepel@igecuniv.csita.unige.it

${ }^{k}$ Zoology Department, Bari University, Via Orabona 4, 70125 Bari, Italy. r.sandulli@bioserver.uniba.it

${ }^{1}$ Service de l'environnement, 3 av. de Fontvieille, MC 98000, Monaco. pvk@mcn.mc

(Received 24 February 1998, revised 27 August 1998, accepted 1 September 1998)

\begin{abstract}
Fourteen years after the first observation of Caulerpa taxifolia (Valh) C. Agardh in the northwestern Mediterranean Sea, this green alga of tropical origin is now present in five countries (Spain, France, Monaco, Italy and Croatia). By the end of 1997 , more than $46 \mathrm{~km}^{2}$, at depths of between 0 and $50 \mathrm{~m}$, were found to be affected by this expansion. A standardization of the cartographic procedure is proposed here. Such a standardization is necessary to compare maps produced by various organizations from different countries. For a given independent station, it is based on the definition of three levels of colonization:

- Level I refers to a station where one or several colonies less than $100 \mathrm{~m}$ apart cover a total surface area inferior to $1000 \mathrm{~m}^{2}$;

- Level II refers to a station where several colonies less than $250 \mathrm{~m}$ apart totally cover more than $1000 \mathrm{~m}^{2}$ with fragments and small colonies dispersed over a surface area inferior to $10 \mathrm{ha}$;

- Level III is attained when several large colonies are dispersed over a surface area superior to 10 ha, with a total covered surface of more than $1000 \mathrm{~m}^{2}$, impossible to map with precision due to its size.
\end{abstract}


For each of these colonization levels, descriptive parameters can be used to precisely describe the situation: covered surface area, dispersion surface (i.e. "affected" zone), estimation of very large affected zones (i.e. "concerned" zones) and the portions of the coastline along which an affected or concerned zone can be found. $\odot$ Elsevier, Paris / Ifremer / Cnrs / Ird

\section{cartography / Caulerpa taxifolia / standardization / Invasive species / Mediterranean Sea}

Résumé - Standardisation des représentations cartographiques de l'expansion de Caulerpa taxifolia en Méditerranée. Quatorze années après la première observation de Caulerpa taxifolia en Méditerranée nord-occidentale, cette algue d'origine tropicale est présente dans cinq pays (Espagne, France, Monaco, Italie et Croatie). À la fin de l'année 1997, plus de $46 \mathrm{~km}^{2}$ de fonds, situés essentiellement entre 0 et $50 \mathrm{~m}$ de profondeur, sont concernés à divers degrés par cette invasion. Une standardisation de la représentation cartographique est proposée. L'objectif de cette normalisation est de pouvoir comparer les cartes produites par divers organismes appartenant à plusieurs pays. Elle est basée sur la définition, pour une stàtion donnée, de trois niveaux de colonisation :

- Le nivcau I correspond à une station où se développent une ou plusieurs colonies (réparties à moins de $100 \mathrm{~m}$ les unes des autres) et couvrant au total une surface inférieure à $1000 \mathrm{~m}^{2}$;

- Le niveau II correspond à une station où de nombreuses colonies (réparties à moins de $250 \mathrm{~m}$ les unes des autres) couvrent au total plus de $1000 \mathrm{~m}^{2}$ et sont dispersées dans une surface inférieure à 10 ha ;

- Le niveau III correspond à une station où les colonies sont disséminées dans une zone supérieure à 10 ha et pour lesquelles la surface totale couverte (très supérieure à $1000 \mathrm{~m}^{2}$ ) n'est plus cartographiable avec précision.

Pour chaque niveau un ensemble de paramètres descriptifs permet de préciser la situation : surface totale couverte, surface atteinte, estimation des larges surfaces atteintes (ou surface concernée), linéaire de côte devant lequel on trouve des surfaces atteintes ou concernées. (O) Elsevier, Paris / Ifremer / Cnrs / Ird

\section{cartographie / Caulerpa taxifolia / standardisation / espèces envahissantes / mer Méditerranée}

\section{INTRODUCTION}

The tropical alga Caulerpa taxifolia (Vahl) C. Agardh, a species currently spreading throughout the Mediterranean Sea, was first observed in Monaco in 1984 [13]. At that time, only one square metre of $C$. taxifolia was observed. By 1990 , this alga had spread to cover more than 1 ha in Monaco and, during this same year, was observed in France, at Cap Martin, a few kilometres east of Monaco. After 14 years of continuous expansion, the alga is present to a varying degree over approximately 4600 ha of the littoral zone at depths of between 0 and $50 \mathrm{~m}$, and this along the coasts of five countries: Spain, France, Monaco, Italy and Croatia [21].

This ubiquitous alga is able to colonize most Mediterranean habitats (Posidonia or Cymodocea seagrass beds, rocks with photophilic or sciaphilic algae, steep cliffs with sponges and sea fans, coarse and muddy sands), up to a $100 \%$ cover throughout the year. The only exceptions are unstable substrates such as ripple-marked sediments and shallow rocky shores exposed to strong wave action, on both of which $C$. taxifolia only grows as temporary colonies.

Mapping the expansion of Caulerpa taxifolia in the Mediterranean Sea is necessary for a number of reasons:
1) to follow its progression from one year to the next;

2) to assess its environmental impact and analyze the regression of outcompeted species;

3 ) to estimate C. taxifolia biomass and other related biological data;

4) to calibrate computer models to simulate its spread $[10,11]$

5) to describe the situation to decision-makers for possible control measures.

Numerous maps describing $C$. taxifolia spread have been published in the past six years $[1,4,2,3,7,8,9,15,16$, $17,18,19,20,21,22,23]$. Nine additional references are available from the first [6] and second [24] workshops on C. taxifolia.

The rapid colonization rate of this species requires a time-consuming/constant and costly effort in order to provide up-to-date information. Furthermore, as the extent of colonization increases, mapping precision decreases. Therefore, in order to provide a standardized description of the situation, a normalization of the cartographic procedure is proposed in the present paper which takes into account the dynamic aspect of $C$. taxifolia's rapid expansion. 


\section{DEFINITIONS}

From field observations, one can roughly distinguish three levels of colonization of a new patch of Caulerpa taxifolia, and this from the first settlement of a few fragments up to the expansion over large areas. Before a detailed presentation of these three levels can be made, some key words must be defined which help to describe the main characteristics of a station (table I).

Station: a C. taxifolia "station" is a surface area colonized to a varying degree by one or more colonies located close to each other [16]. In most cases, several different substrates or ecosystems may be invaded in a single station. Thus, in the naming of the station, we recommend that it be given the name of the nearest geographic locality (or the name of a known place hetween two localities), rather than a name referring to a specific substrate or ecosystem. The older the colonization, the greater the number of separate colonies and the distance between them. As a result, and for each level of colonization, specific distances are proposed (in metres or kilometres) to clearly distinguish one station from another.
Covered surface: when a single colony is growing, it expands in dense clusters, with up to $100 \%$ bottom cover in the middle and $50 \%$ cover at the periphery. The total area over which $C$. taxifolia grows with these coverage percentages is considered to be "covered". Based on field observations, such colonies are easy to map underwater using scuba-diving when the covered surface remains below $1000 \mathrm{~m}^{2}$. The total covered surface of a station is the sum of the surface areas of the various colonies present (figure 1).

Affected surface: the dispersion pattern of the colonies at a station is an important parameter as it allows one to describe the characteristics of the vegetative dissemination of this alga. All the suitable substrates within the area of dispersal can eventually be colonised. Thus, the delimitation of the perimeter in which all the colonies, big or small, are growing is a convex polygon corresponding to the "affected" zone (figure l).

Concerned surface: when the affected zone is larger than 10 ha, field observations have revealed that it is increasingly difficult to delimit the convex polygon of these large affected zones. Under these conditions, only a

Table I. Summary table of proposed levels for each type of colonization and the main descriptive parameters to be measured. +: applicable; -: not applicable.

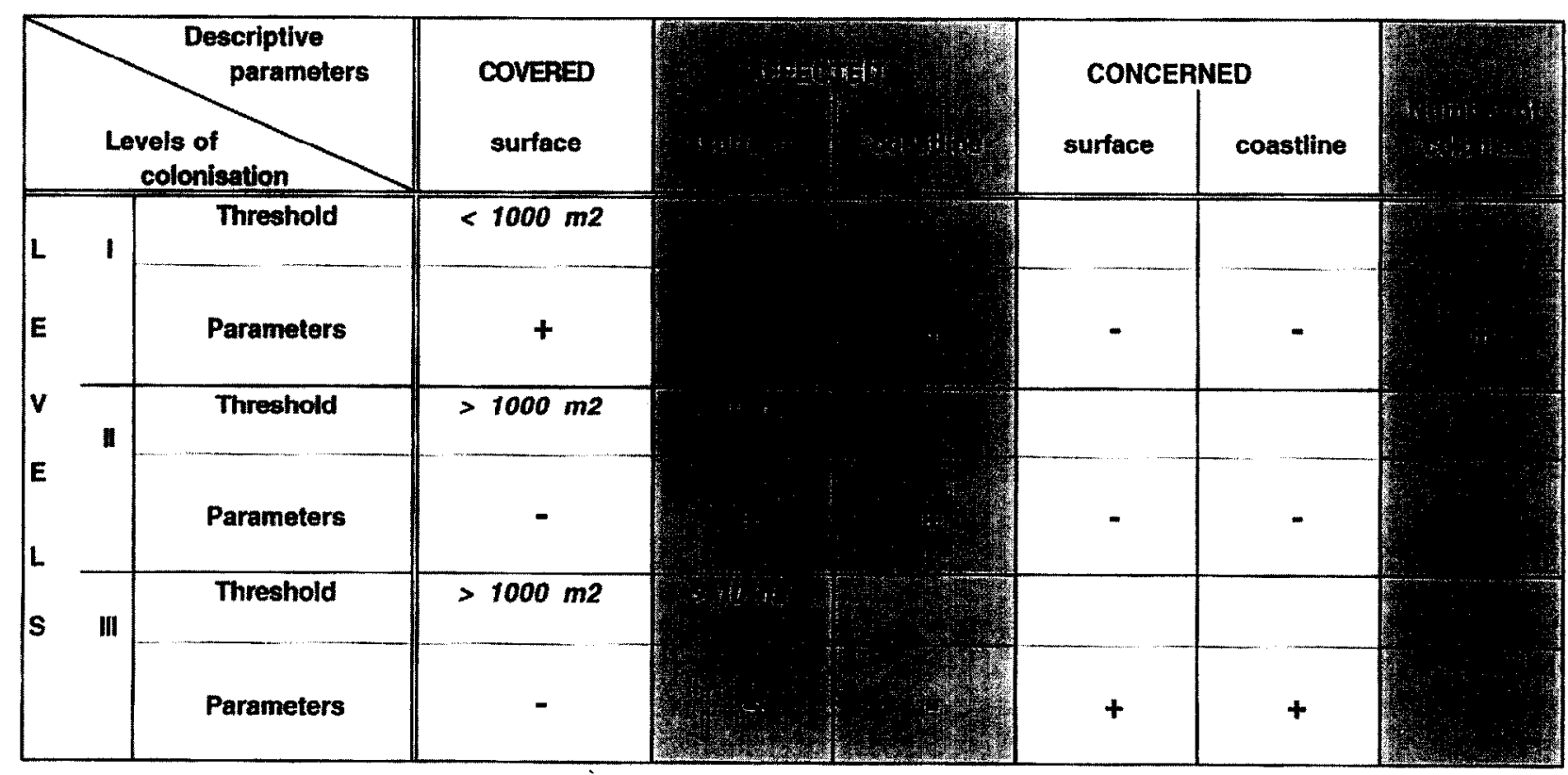

(+: applicable; -: not applicable) 


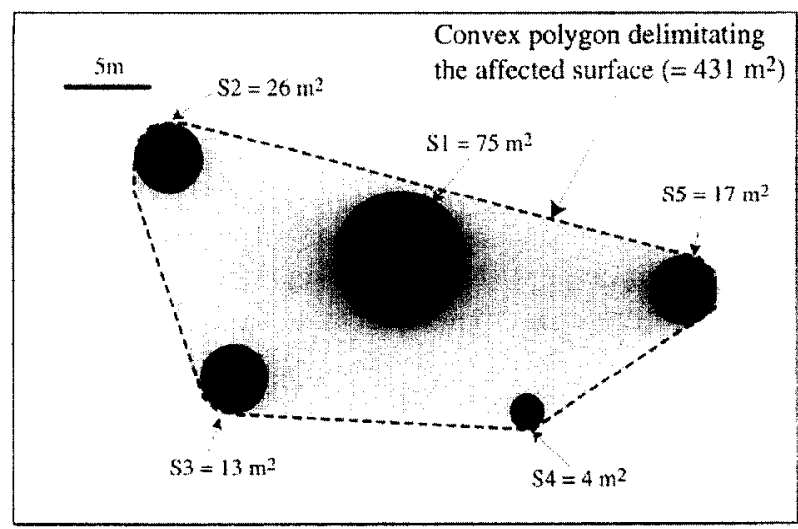

Figure 1. Simplified representation of a station with five colonies ( $S 1$ to $S 5$ ) exhibiting various degrees of bottom cover. In black, the covered surfaces with up to $100 \%$ cover in the centre and $50 \%$ at the margins. The total covered surface for this station is the sum of $\mathrm{S} 1$ to $\mathrm{S} 5$, amounting to $135 \mathrm{~m}^{2}$. The affected surface corresponds to the area of the convex polygon enclosing and including the five colonies $\left(431 \mathrm{~m}^{2}\right)$

rough evaluation of the affected surface area remains possible using conventional mapping methods. These crudely evaluated zones, which should include many local observations confirming the presence of the alga over a large area (i.e. $>10$ ha), are named the "concerned" zones.

Affected or concerned coastline: this parameter refers to the length of coastline (in metres) along which one can observe an affected or concerned zone.

\section{METHODS FOR CARTOGRAPHIC STANDARDIZATION}

Three levels of Caulerpa taxifolia expansion may be codified on a map, from the settlement of the first few fragments to the defining of vast zones invaded by the alga to a varying degree.

Table I summarizes all parameters used to describe the three levels of colonization.

\subsection{Level I (figure 2)}

The first level of colonization corresponds to a station where a single colony or several small colonies are spreading. These stations are often characterized by a central colony surrounded by smaller satellite colonies. The total covered surface area is smaller than $1000 \mathrm{~m}^{2}$. Level I corresponds to the first years of invasion, roughly from the arrival of the first fragments until the third or fourth year of development [16]. As the rate of spread is usually high, Level I rapidly evolves to a Level II colonization.

In a Level I situation, colonies less than $100 \mathrm{~m}$ apart belong to the same station. Otherwise, they are considered to belong to different stations.

Figure 2 shows various examples of Level I stations. The following parameters may be used to describe this situation:

- the total surface area covered by all the colonies, i.e. the "covered zone". For each station, the number, position and size of the colonies may be represented on the map,

- for each station, the surface area of the convex polygon enclosing all the colonies, i.e. the "affected zone",

- for each station, the portion of the coastline directly in front of the affected zone, i.e. the "affected coastline",

- the type of initial substratum on which C. taxifotia is expanding,

- the range of affected depths.

\subsection{Level II (figure 3)}

The second level of colonization corresponds to a station where the total covered surface area of several colonies is greater than $1000 \mathrm{~m}^{2}$, with an affected zone inferior to $10 \mathrm{ha}$. In this type of situation, it is too time consuming and costly to map such an extensive (and rapidly evolving) colonization using conventional mapping procedures accurately. One can, however, establish the limits of the convex polygon enclosing all peripheral fragments (i.e. the "affected" zonc).

In Level II, colonies less than $250 \mathrm{~m}$ apart belong to the same station. Otherwise, they are considered to belong to different stations. For example, three $600 \mathrm{~m}^{2}$ colonies (whose total covered surface area is equal to $1800 \mathrm{~m}^{2}$ ), located $200 \mathrm{~m}$ from each other, belong to a single Level II station whose affected zone must be measured and plotted on the map. If these colonies were situated more than $250 \mathrm{~m}$ apart, they would he descrihed as three distinct Level I stations.

This colonization level is characterized by a rapid expansion of $C$. taxifolia over a wide range of available substrates. This type of colonization can be observed roughly four to five years after the arrival of the first fragments at a site. Such an expansion rapidly leads to a level III colo- 


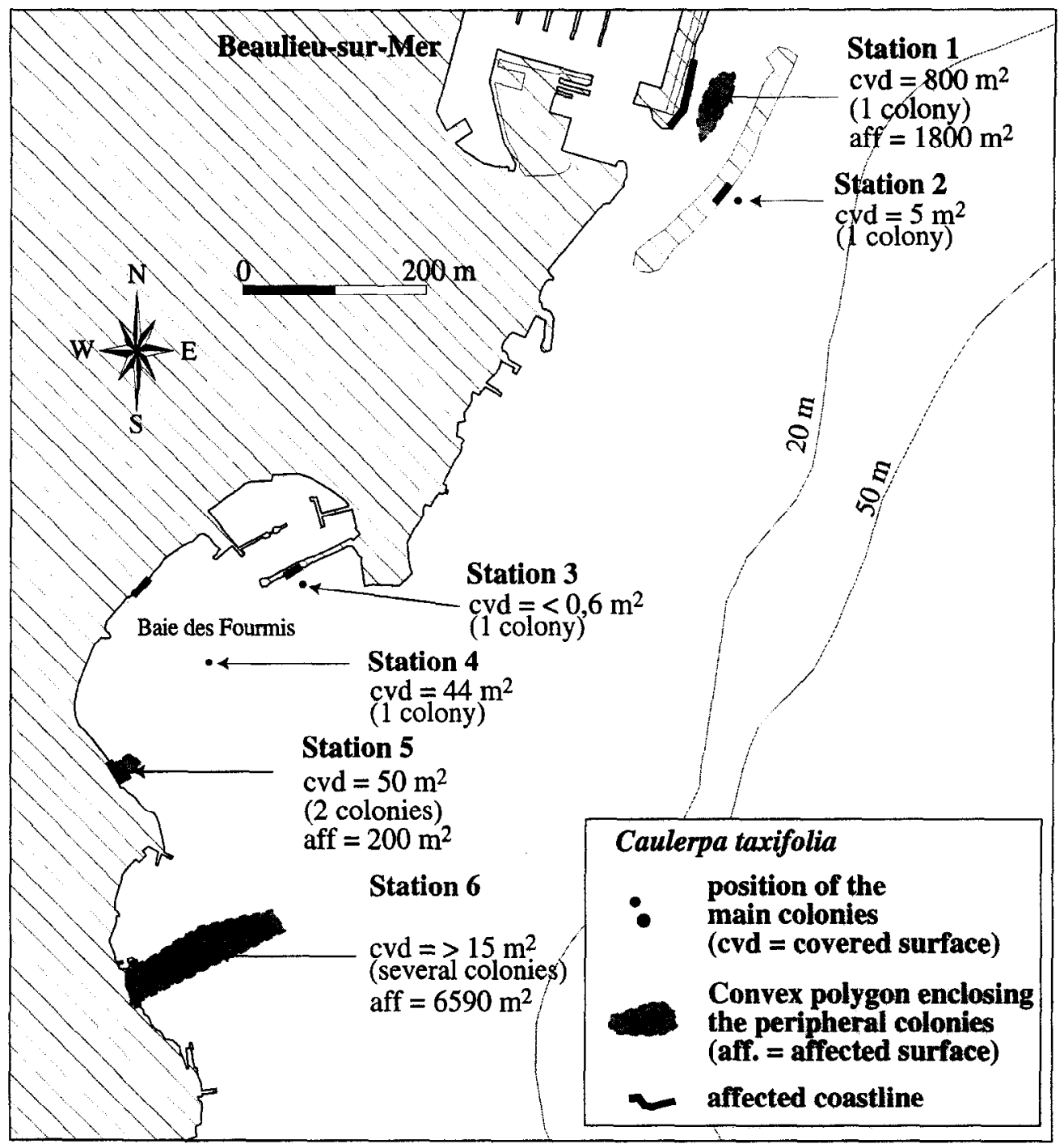

Figure 2. Example of several Level I stations. All stations are more than $100 \mathrm{~m}$ apart. Baie des Fourmis, Beaulieu-sur-Mer (France), 1996.

nization in the few years following the beginning of the expansion.

Figure 3 shows an example of a Level II station. For each independent station, the following parameters can be used to describe this situation:

- the surface area of the convex polygon enclosing all the peripheral colonies, i.e. the "affected zone". The location of the largest and most densely covered colonies may be represented on the map,

- the portion of the shoreline directly in front of the affected zone, i.e. the "affected coastline",
- the main types of initial substratum on which $C$. taxifolia is expanding,

- the range of affected depths.

\subsection{Level III (figure 4)}

The third level of colonization corresponds to one or several affected zones whose total surface area is greater than 10 ha. At this level of colonization, one will find several large colonies whose bottom cover exceeds $1000 \mathrm{~m}^{2}$ and, in the vicinity of these, numerous smaller peripheral colonies and fragments. It is too time-consuming and costly to map the affected zones when dealing 


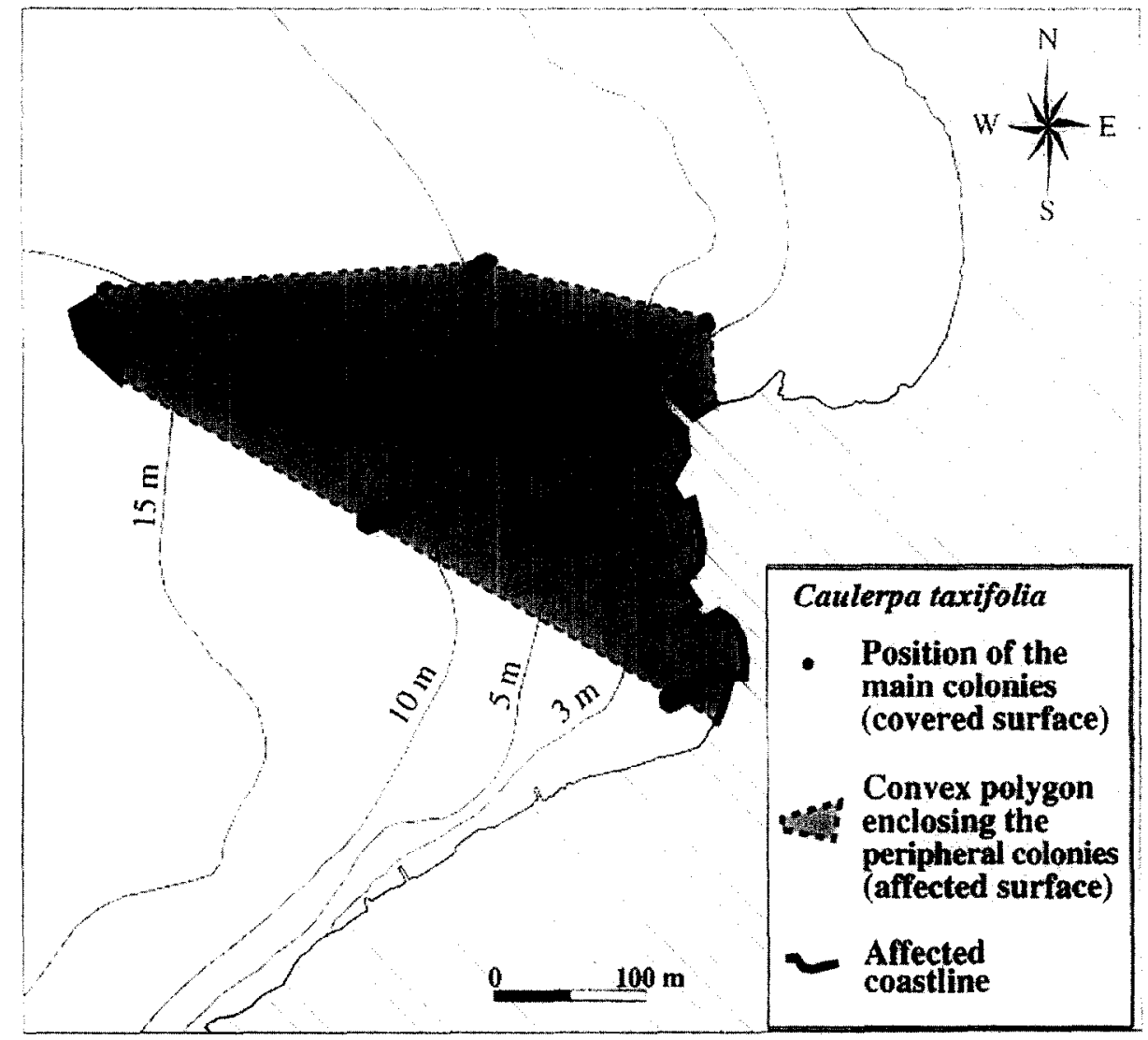

Figure 3. Example of a Level II station. All colonies are less than $250 \mathrm{~m}$ apart. Only the peripheral and largest colonies are mentioned. Passable area, Villefranche-sur-Mer (France), 1996.

with this level of colonization. One can, at best, define the lateral and bathymetric limits of these colonies scattered over several hectares. This roughly estimated area may be defined as a "concerned" zone.

Lateral limits should be defined based on the position of the peripheral colonies. Another possibility involves the use of geographical limits (eg. from one cape to another) between which all colonies are observed.

The bathymetric limit should be established according to the position of the deepest colonies [2]. Bathymetric ranges can also be used ( 0 to $5 \mathrm{~m}, 5$ to $10 \mathrm{~m}, 10$ to $20 \mathrm{~m}$, 20 to $30 \mathrm{~m}$, etc.). Thus, if a $C$. taxifolia fragment is found at a depth of $25 \mathrm{~m}$, then the 20 to $30 \mathrm{~m}$ bathymetric range is considered to be "concerned".

In Level III, colonies less than $1 \mathrm{~km}$ apart belong to the same station. Otherwise, they are considered to belong to different stations
This evaluation of the overall situation must be based on numerous field observations. In such highly invaded areas, the alga can easily be observed and clearly identified by fishermen, divers, boaters, swimmers, etc. The information provided by such sea users is then gathered by scientists who can subsequently include it in their cartographic work to delimit a Level III zone.

\subsection{Maps with various levels of colonization}

To represent complex situations on small scale maps presenting several levels of colonization, it is suggested to use circles whose sizes are proportional to the level of colonization, and convex polygons with dotted lines for Level III stations. The circles and polygons can be coloured in tones of black according to the level of colonization, with $100 \%$ black for the covered zones, $50 \%$ black for the affected zones and $15 \%$ black for the concerned zones. Figure 5 is an example of such a representation. 


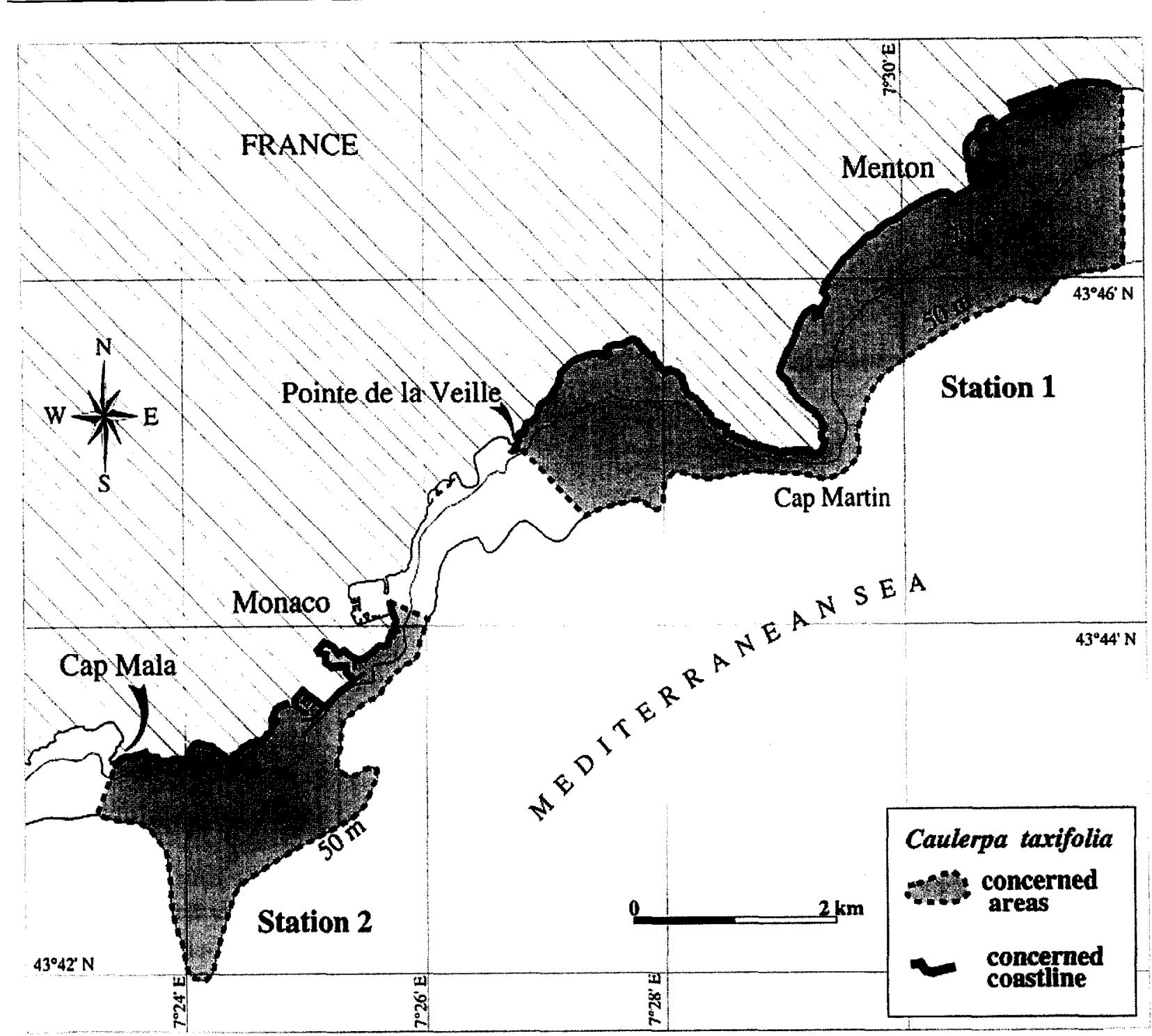

Figure 4. Example of two Level III stations near Monaco and Menton (1993). Station 1 extends from the Italian border to Pointe de la Veille (France); station 2 from Monaco to Cap Mala (France). The two stations are more than $1 \mathrm{~km}$ apart. The $50 \mathrm{~m}$ bathymetric line is taken as the lower depth limit. Total concerned surfaces (in 1993): 1300 ha.

\section{GRAPHIC REPRESENTATION OF CAULERPA TAXIFOLIA}

In order to standardize the graphic representation of Caulerpa taxifolia on maps, a specific symbol is proposed here (figure 6). It is to be added to those proposed by Meinesz et al. [14].

For black and white maps, we suggest that dark black (100\% black) be used for the "covered" surfaces, dense grey (50\% black) for the "affected" surfaces and light grey ( $15 \%$ black) for the "concerned" surface areas.
For colour maps, three tones of yellow-green are proposed:

- covered zones: Cyan $50 \%$; Magenta $0 \%$; Yellow $100 \%$; Black $0 \%$,

- affected zones: Cyan $43 \%$; Magenta $0 \%$; Yellow $97 \%$; Black $0 \%$,

- concerned zones: Cyan $41 \%$; Magenta $0 \%$; Yellow $96 \%$; Black $0 \%$. 


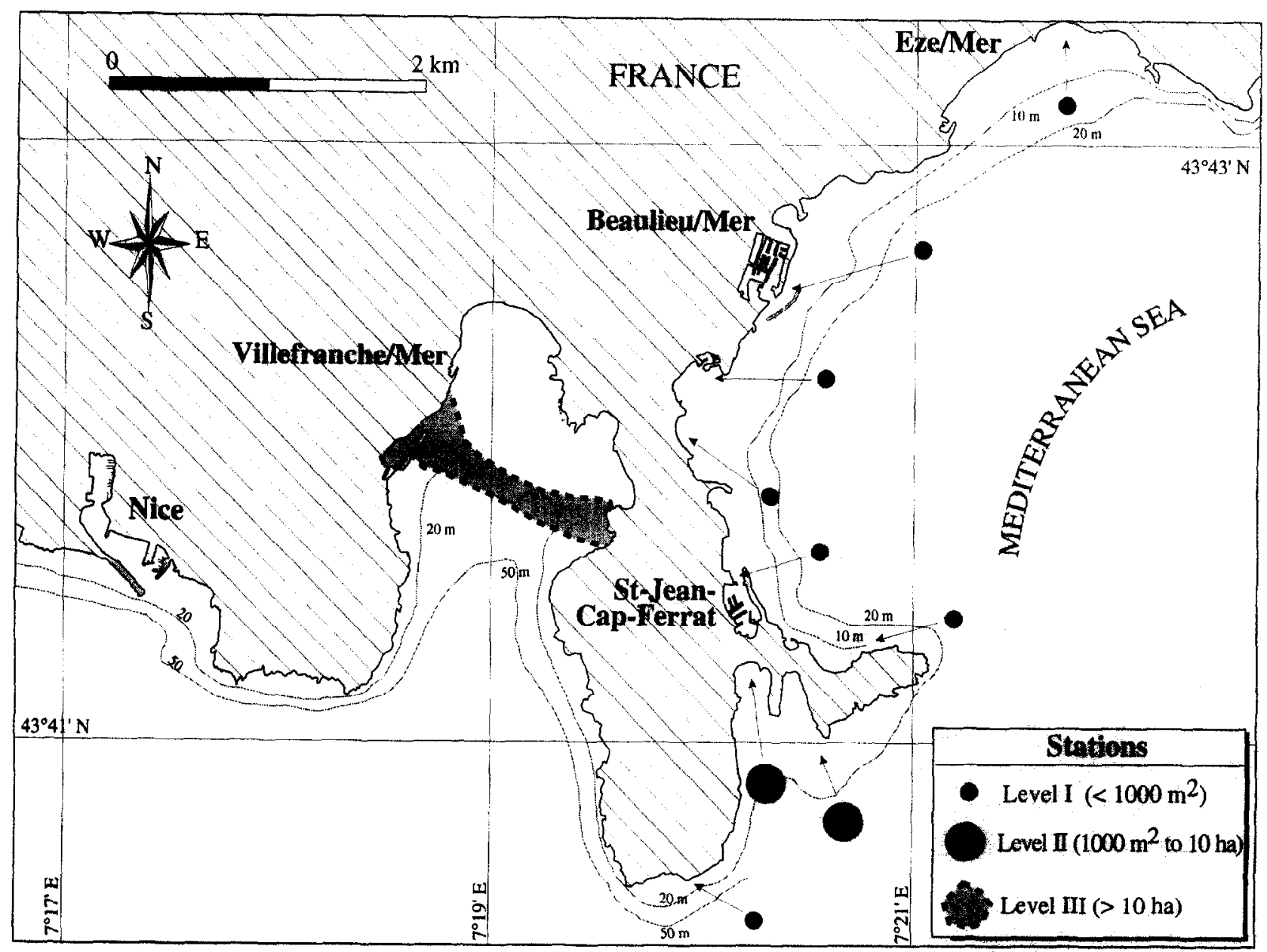

Figure 5. Overall map of Caulerpa taxifolia expansion. Size and colour of symbols is proportional to levels of colonization. Nice to Eze-surMer, 1997.

\section{QUANTITATIVE EVALUATION OF CAULERPA TAXIFOLIA COLONIZATION}

To quantitatively describe the overall situation in one or several countries characterized by geographically distinct stations colonized to a varying degree, the following procedure is proposed:

- present the situation level by level by adding together identical parameters for every station (i.e. sum of covered surface areas, sum of affected surface areas, sum of concerned surface areas, sum of affected coastlines and sum of concerned coastlines).

- add similar parameters such as:

- affected surface areas of Level I and II stations and concerned surface areas of Level III stations,
- affected coastlines of Level I and II stations and concerned coastlines of Level III stations.

- estimate dissemination by counting both the number of stations according to level and the total number of stations (all three levels included).

- identify the groups of stations based on a distance criterion (i.e. the distance between two adjacent groups of stations) and this in order to increase our understanding of the geographical dispersion of colonies. For instance, it is recommended that groups of stations that are less than 1, 10,100 and $/$ or $500 \mathrm{~km}$ apart be separated.

These overall assessments should be performed yearly in order to fully comprehend the dynamics of $C$. taxifolia expansion. As the precision of the final maps is directly correlated with the number of field observations, the 


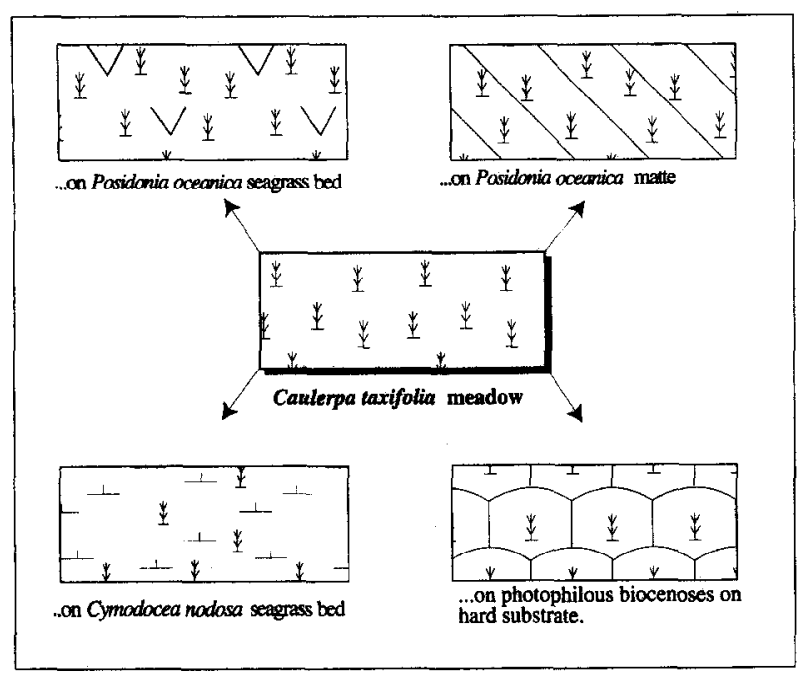

Figure 6. Proposal for a graphic representation of Caulerpa taxifolia meadows and examples of $C$. taxifolia associated with various biocenoses. The symbol for $C$. taxifolia is to be added to those proposed by Meinesz et al. [16] to represent the main Mediterranean substrates, ecosystems, biotopes and species.

Symbol size and density are not proportional to population or species percentage bottom cover. manner by which they were obtained and the cartographic method used, etc., all of these methodological aspects need to be described in order to facilitate comparisons between maps.

\section{CONCLUSION}

In the present study, a standardization procedure is proposed which would allow comparisons between maps produced by the various organizations in charge of mapping the expansion of Caulerpa taxifolia in the Mediterranean Sea. These standardized maps, once included in an international monitoring network, would greatly facilitate the dissemination of information between organizations.

\section{Acknowledgments}

This study was partly financed by CEE funds (DG XI, $\mathrm{n}^{\circ}$ LIFE95/F/A31/EPT/782), under the management of C.-F. Boudouresque. We thank all GIS-Posidonie members for their strong involvement in this program and $\mathbf{R}$. Delepine for his careful reading of the manuscript and helpful suggestions.

\section{REFERENCES}

[1] Belsher T., Cartographie sous-marine de l'algue tropicale Caulerpa taxifolia, campagne $\mathrm{n}^{\circ} 1 \mathrm{du}$ N. O. Roselys 2 , rapport Ifremer, Centre de Brest (1992) $39 \mathrm{p}$.

[2] Belsher T., Meinesz A., Deep-water dispersal of the tropical alga Caulerpa taxifolia introduced into the Mediterranean, Aquatic Bot. 51 (1995) 163-169.

[3] Belsher T., Deslous-Paoli J.-M., Dagault F., Dimeet J., Raillard J.-M., Eric E., Boutbien M., Prudhomme C., Grillo M.-C., Pucci R., Veglia A., Acquisition d'éléments qualitatifs et quantitatifs sur l'expansion de Caulerpa taxifolia en 1995-1996 (Alpes-Maritimes et principauté de Monaco), rapport Ifremer, Centre de Brest/DEL (1997) $50 \mathrm{p}$.

[4] Belsher T., Youenou G., Dimeet J., Raillard J.-M., Bertrand S., Mereau N., Évolution de Caulerpa taxifolia devant les côtes des Alpes-Maritimes et de la principauté de Monaco, observations par vidéo tractée (mars et octobre 1992), rapport Ifremer, Centre de Brest/DEL (1993) $36 \mathrm{p}$.

[5] Belsher T., Youenou G., Dimeet J., Raillard J.-M., Bertrand S., Mereau N., Éléments cartographiques de Caulerpa taxifolia en Méditerranée (Alpes-Maritimes et Monaco, 1992), Oceanol. Acta 17 (4) (1995) 443-451.
[6] Boudouresque C.-F., Meinesz A., Gravez V. (Eds.), First international workshop on Caulerpa taxifolia Nice, France, 17-18 janvier 94, GIS Posidonie publ., Marseille, (1994) 391 p.

[7] Ferla S., Tomasello A., Ferreri B.M., Fradà Orestano C., Calvo S., Preliminary notes on epiphyte macroflora of Caulerpa taxifolia in the Strait of Messina, Giorn. Bot. Ital. 128 (6) (1994) 1096-1098.

[8] Fradà Orestano C., Calvo S., Ferreri B.M., First record of Caulerpa taxifolia (Vahl) C. Agardh in the southwestern Mediterranean, Giorn. Bot. Ital. 128 (3-4) (1994) 813-815.

[9] Fredj G., Di Geronimo S., Gay G., Inventaire et cartographie des biocénoses benthiques de la principauté de Monaco, campagne en mer du 19 au 29 septembre 1992, rapport du département des travaux publics et des affaires sociales, service de l'environnement, principauté de Monaco (1993) 1-86.

[10] Hill D.R.C., Coquillard P., Vaugelas J. de, Discrete event simulation of alga expansion, Simulation 68 (5) (1997) 269 277.

[11] Hill D.R.C., Coquillard P., Vaugelas J. de, Meinesz A., An algorithmic model for invasive species: application to Caulerpa taxifolia (Vahl) C. Agardh development in the northwestern Mediterranean Sea, Ecological Modelling 109 (1998) 251-265. 
[12] Meinesz A., Modes de dissémination de l'algue Caulerpa taxifolia en Méditerranée, Comm Int. Exp. Sc. Med., rapp. Comm. int. Mer Medit. 33 (1992) 44

[13] Meinesz A., Hesse B., Introduction et invasion de l'algue tropicale Caulerpa taxifolia en Méditerranée nord-occidentale, Oceanol. Acta 14 (4) (1991) 415-426.

[14] Meinesz A., Boudouresque C.F., Falconetti C., Astier J.M., Bay D., Blanc J.J., Bourcier M., Cinelli F., Cirik S., Cristiani G., Geronimo I. di, Giaccone G., Harmelin J.G., Laubier L., Lovric A.Z., Molinier R., Soyer J., Vamvakas C., Normalisation des symboles pour la représentation et la cartographie des biocénoses benthiques littorales de Méditerranée, Ann. Inst. océanogr. Paris, 59 (2) (1983) 155-172.

[15] Meinesz A., de Vaugelas J., Benichou L., Caye G., Cottalorda J.-M., Delahaye L., Febvre M., Garin S., Komatsu T., I.emée R., Mari X., Molenaar H., Perney L., Venturini A., Suivi de l'invasion de l'algue tropicale Caulerpa taxifolia en Méditerranée : situation au 31 dêcembre 1992, Ed. laboratoire environnement marin littoral, université de Nice-Sophia-Antipolis (1992) $80 \mathrm{p}$.

[16] Meinesz A., de Vaugelas J., Hesse B., Mari X., Spreading of the introduced tropical green alga Caulerpa taxifolia in northern Mediterranean waters, J. appl. Phycol. 5 (1993) 141147.

[17] Meinesz A., Ballesteros E., Blachier 1., Cinelli F., Cuttalorda J.-M., Fradà Orestano C., Komatsu T., Lemée R., Molenaar H., Morucci C., Pou S., Sandulli R., Tripaldi G., Vaugelas J. de, Latest news on the spread of Caulerpa taxifolia introduced in the Mediterranean, $5^{\text {th }}$ int. Phycol. Congress, Qingdao 164 (1994) 28.

[18] Meinesz A., Vaugelas J. de, Cottalorda J.-M., Benichou L., Blachier J., Caye G., Chambet P., Delahaye L., Febvre M., Garin S., Komatsu T., Lemée R., Mari X., Molenaar H., Perney L., Pietkiewicz D., Suivi de l'invasion de l'algue tro- picale Caulerpa taxifolia en Méditerranée : situation au 31 décembre 1993, Ed. laboratoire environnement marin littoral, université de Nice-Sophia-Antipolis (1994) 100 p.

[19] Meinesz A., Vaugelas J. de, Cottalorda J.-M., Caye G., Charrier S., Commeau T., Delahaye L., Febvre M., Jaffrenou F., Molenaar H., Pietkiewicz D., Suivi de l'invasion de l'algue tropicale Caulerpa taxifolia devant les côtes françaises de la Méditerranée : situation au 31 décembre 1994, Ed. laboratoire environnement marin littoral, université de Nice-SophiaAntipolis (1995) $116 \mathrm{p}$.

[20] Meinesz A., Cottalorda J.-M., Chiavérini D., Braun M., Carvalho N., Febvre M., Ierardi S., Mangialajo L., Passeron Seitre G., Thibaut T., Vaugelas J. de, Suivi de l'invasion de l'algue tropicale Caulerpa taxifolia devant les côtes françaises de la Méditerranée : situation au 31 décembre 1996, Ed. laboratoire environnement marin littoral, université de Nice-SophiaAntipolis (1997) $190 \mathrm{p}$.

[21] Meinesz A., Cottalorda J.-M., Chiavérini D., Cassar N., Vaugelas J. de, Suivi de l'invasion de l'algue tropicale Caulerpa taxifolia devant les côtes françaises de la Méditerranée : situation au 31 décembre 1997, Ed. laboratoire environnement marin littoral, université de Nice-Sophia-Antipolis (1998) $250 \mathrm{p}$.

[22] Pou S., Ballesteros E., Delgado O., Grau A.M., Riera F., Weitzmann B., Sobre la presencia del alga Caulerpa taxifolia (Vahl) C. Agardh (Caulerpales, Chlorophyta) en aguas costeras de Mallorca, Boll. Soc. Hist. Nat. Balears 36 (1993) 84-90.

[23] Relini M., Torchia G., Prima segnalazione di Caulerpa taxifolia in acque italiane, Doriana 6 (279) (1992) $1-4$.

[24] Ribera A., Ballesteros E., Boudouresque C.-F., Gomez A., Gravez V., (Eds.) Second international workshop on Caulerpa taxifolia, Barcelona, Spain, 15-17 Decembre 94, Universitat de Barcelona publ., Barcelona (1996) 457 p. 